\title{
Moy Sand and Gravel
}

'Life is indeed no more than "a misprint / in the sentence of death". Muldoon's memorable verses from 'Now, Now' in the previous volume Hay (23) anticipate and condense the concerns of precarious human existence and linguistic undecidability in Moy Sand and Gravel. The line also anticipates the status and signifiance of the term 'sentence' in this volume. The sentence, in all its senses of grammar, writing, structure and law, becomes a unit for attention and experimentation. This concentration on the sentence indicates a motion in Muldoon's poetry from the minutiae and deconstructive forces of language towards larger structures and more constructive tendencies. Yet Muldoon's preoccupation with language, which resulted in so much adlinguisticism, plot and play in Hay, remains. Many titles in his ninth volume of poetry from 2002 highlight his linguistic intensity, and continue to develop his characteristic scrutiny of language. 'Tell,' 'As,' 'On,' 'Famous First Words,' 'The Grand Conversation,' 'A Brief Discourse on Decommissioning' and 'At the Sign of the Black Horse, September 1999' all draw attention to words, functions, concepts, ideas and signs of language. The first three poems enlarge on the importance of the minutiae of language - prepositions and single words - in a way both William Empson and Jacques Derrida would recognise. ${ }^{1}$ Polysemantic equivocation interacts with larger ideas and corresponds with several shifting contexts in all

1 'I shall frequently pounce on the least interesting aspect of a poem,' Empson declares in the beginning of Seven Types of Ambiguity (7). He continues: 'I shall now mount on the second of the hobby-horses with which I am ending off this chapter, and examine the way Shakespeare uses a combination of "and" and "of,"' before his extensive analysis on the meaning of the two words in Shakespeare's work (88-101). Derrida exploits "as" as a linguistic crow bar to open the can of deconstructive worms. In his philosophical shakedown with Lévi-Strauss on structural linguistics one of his paragraphs runs: 'If we wished to elaborate the question of the model, we would have to examine all the "as"-s and "likewise"-s that punctuate the argument, ordering and authorizing the analogy between phonology and sociology, between phonemes and the terms of kinship. "A striking analogy," we are told, but the functioning of its "as" shows us quickly enough that this is a very infallible but very impoverished generality of structural laws, no doubt governing the systems considered, but also dominating many other systems; a phonology exemplary as the example in a series and not as the regulative model. But on this terrain questions have been asked, objections articulated; and as the epistemological phonologism establishing a science as a master-model presupposes a linguistic and metaphysical phonologism that raises speech above writing, it is the last that I shall first try to identify' See Derrida, Of Grammatology, 103. Derrida's locus classicus for exploding hermeneutic structures in Irish literature is his reading of Joyce, 'Ulysses Gramophone: Hear 
three poems, with an obvious accent on the writerly. 'Tell' bears resemblance to 'Crossing the Line' and 'The Plot' in its integration of undecidable linguistic connotations and shifting alliances between cultures in conflict. Festivity and formality dominate 'On' and 'As,' which focus on minimal and frequently ignored units of language, and incorporate a certain media self-consciousness. The former fourteen liner plays on stage production and audience sections. The latter, 'As,' Muldoon's 99-line millennium poem broadcast on RTÉ on $3^{1}$ December 1999, Millennium Eve, plays on the adverb, conjunction and noun of multiple linguistic functions and meanings, activates the concept of the simile, and parallels the freewheeling associations of the last twenty-two 'of'-stanzas in 'Incantata' $(A C, 21-28)$. The radio poem records the sparkling sounds of metric intoxication, linguistic relish and historical changes in a poem of pyrotechnic splendour that displays the mesmerising brilliance of Muldoon's poetic insouciance: a count-down of Muldoonia and of the linguistic century. 'Famous First Words,' a series of alphabetic conundrums and in many ways an abecedarian mini-Madoc, a poetic sibling of 'Errata' $(H, 88)$, presents thirteen couplets of enigmatic riddles that necessitate excursions in a plethora of encyclopaedias and reference works. Two poems on pomegranates, 'Paul Valéry: Pomegranates' and 'Pineapples and Pomegranates,' displace, first, their own allusions to hand grenades, then, second, reference to their own meaning. In two sentences of poetry and politics, 'Guns and Butter' questions the censuring of radical and explosive poetics from paramilitary camps. 'A Brief Discourse on Decommissioning' offers a catachrestic mini-terrorist narrative in a single sentence. 'The Grand Conversation' balances larger contexts and individual matters. The final poem, as always, orchestrates the volume's sounds and zest, words and weirdness, signs and semiosis, as the title clearly demonstrates: 'At the Sign of the Black Horse, September 1999.' Some of these poems take new turns on old territory, some of them break new ground; some of them are cerebral and cold, some of them compassionate and caring - all of them centre on thoughts, definitions, ideas and concepts of language, and all of them excavate the spaces of language between sign and referentiality, between signs and metaphysics. And the spaces of language itself.

Muldoon's language consciousness, which so many of the titles highlight, manifests itself from $\mathrm{A}$ to $\mathrm{Z}$ in this volume, in form, feature, line, lexicon, sound and structure as much as in the unexpected, unseen and unheard features of the volume. Numerological solutions and stanzaic versatility configure temporal frames and prevalent themes. Neologisms, lexical rarities, Gaelic and other

Say Yes in Joyce,' in Acts of Literature, ed. Derek Attridge (New York and London: Routledge, 1992), 253-310. 
languages, linguistic errancy, popular idiom and the weird and the wonderful words of a poet who confesses his love for the Oxford English Dictionary and who devotes a whole book chapter to 'the urge towards the cryptic, the encoded, the runic, the virtually unintelligible' still enhance the diversity of Muldoon's poetic language. ${ }^{2}$ His zest for rhythm, inimitable chime and cognitive convocations is consolidated here. This time he combines the Gaelic 'mar bheadh' with 'orchestra' (43); 'the smell, like a skunk' with 'Thelonious Monk' (51); and 'Ashkenaz' with 'Mouth and Nose,' 'Auschwitz' and 'Boscobel Beach' (82). In the title poem 'taken aback' and 'travel' yield composite rhymes: 'track' and 'smackety-smack' (8). In 'The Misfits' the names and sounds of 'Grew,' 'Grimley, 'Monk,' and 'Moy' are melded together in 'Montgomery' (10). The horse play on studs and stallions in 'The Whinny' prescribes their movement with the prepuce / of his yard / an unprepossessing puce' (13). In a similar type of double act in 'Winter Wheat' (26), 'something' appears twenty times as a short cut solution for all the unpresentable dimensions of the seedy, and of conception and long gestation in rural relations and intertextual exchange. The multisemiotics of S - from 'Yarrow' ( $A C$, 39-189) resurfaces in 'The Otter' (30). The endeavour to exhaust the polysemantics of the homonym, epitomised by 'They that Wash on Thursday' in Hay (83-84), continues in 'One Last Draw of the Pipe' (21) in the context of smoke signals between Paul Muldoon, W.B. Yeats, Douglas Hyde and Sitting Bull - certainly a series of coded messages for initiates, and possibly from Muldoon to a lot of non-smokers. In the final long finish, which in this volume is cut back to a more manageable size, 'At the Sign of the Black Horse, September 1999,' internal stanzaic chimes extend to a sound distribution in which the first and the final, the second and the penultimate, the third and the triultimate octave chime with each other in continuous introversion. Despite the many syncopations and mud slides, a startling amount of phonetic combinations in this volume sound with the hammer and tongs of a master wordsmith, as if to revert to basics in line with the signals of the title, Moy Sand and Gravel. The connectivity and rhythms that rarely fail to please or provoke are coupled with formal twists in which the master of the mutable sonnet, and of alterratives, sestina variations and composite forms, splices haiku with terza rima in 'News Headlines from the Homer Noble Farm,' spins a one-sentence sestina in 'The Turn,' and recalibrates remarkable refrains in 'The Loaf,' 'An Old Pit Pony' and 'Homesickness.'

The linguistic novelties established and exploited in previous volumes continue. Moy Sand and Gravel articulates, in tandem with his Clarendon lectures from 2000, To Ireland, I, a return to originary processes of location, elements

2 AA, 'A Cat to Catch a Muse: Interview with Paul Muldoon,' 14; Muldoon, To Ireland, I, 5. 
and identity, as the naming of the author's home country and region in both titles indicate. They return, in this respect, with alternative views and reorientations to the dilemmas of expatriation in Why Brownlee Left, and to the directions towards other places and other times in Madoc and The Annals of Chile. They also signal strongly the devotion to Irish matters that, in Muldoon's poetry, cannot be extrapolated from his international interests, and his explorations of aesthetics and larger matters, for example nation and subjectivity. Rather than searching for the right language in which to articulate such concerns and ideas, Muldoon's explorations of language challenge and change such concerns and ideas. As Edna Longley testifies: 'Muldoon often quotes Yeats's reply when asked where he got his ideas from: "looking for the next rhyme."'3 Muldoon's poetic drive frequently leads to the dissemination and deferral of concerns, concepts and ideas in order to uncover the coordinates of similarity and difference that produce and project their coming into being. Increasingly, new sound correspondences for conventional rhymes, scepticism towards linguistic assumptions and distrust of grand philosophical schemes shimmer with creativity in chronology and connectivity to germinate alterratives to dominant concepts of, for example, origins and selfsameness. Muldoon's alterratives of corrosive critique, aporetic accountability, transformative identifications and imaginative forays into what might have been and what might be, continue in this volume. His narrathanographic drives subside. Moy Sand and Gravel's dedication 'for Dorothy and Asher', Muldoon's children, suggests a continuation of the vital verses in The Annals of Chile and the domestic scenes in Hay more than the commemorative and ancestral spirit of large parts of his poetry up to Madoc. The correspondences between Moy Sand and Gravel and To Ireland, I also include, as the latter title signals so crisply, Muldoon's preoccupation with the sentence at this time.

In response to this volume, as to Hay, most critics now notice the inveterate linguistic hyper-self-consciousness of Muldoon's poetry. Laura Quinney starts her review with a paragraph on the language of the volume and Mallory Jensen comments that 'the poems are full of oblique references and hard-to-pronounce Irish words.' The reviewer in The Economist argues that 'Mr. Muldoon may be a conspiracy theorist of language - all rhymers are. ${ }^{5}$ Edna Longley

3 Edna Longley, 'Twists and Turns: Paul Muldoon's Moy Sand and Gravel,' Poetry Review 92, no. 4 (2003), 64 .

4 Laura Quinney, 'In the Studebaker. Moy Sand and Gravel by Paul Muldoon,' London Review of Books, 23 October 2003, 20-21; Mallory Jensen, 'Unraveling Poems of a Modern Irish Bard. Moy Sand and Gravel by Paul Muldoon,' Columbia Spectator, 21 October 2002.

5 AA, 'Reasons for Rhyme,' The Economist, 6 February 2003, http://www.economist.com/ node $/ 1563685$, accessed 10 January 2019. 
writes on Muldoon's' inhabitation of 'that unsettling between-place' between 'word and thing.' She continues: 'If, at one level, Muldoon's poetry constitutes a radical linguistic politics, it is because he continuously implies the norms from which his structures deviate or which they criticise.' ${ }^{6}$ Sean O'Brien, in tandem with Jonathan Allison's ground-breaking article on modality and auxiliary in Muldoon's poetry, draws attention to his enigmatic use of verbal tense, and writes with crystal-clear intellect on the significance of language, from and content:

Yet at the same time the dominant formal feature, rhyme, in which Muldoon is spectacularly ingenious is itself his imagination's leading agent, able to enforce, underline, undermine, contradict, echo, beguile and mislead apparently at will. This copious formality ensures that we never feel a separation of realms between aspects of Muldoon's subject matter. Love, time, parenthood and politics are all part of the same enterprise. ${ }^{7}$

Tom Payne's observation runs parallel to Muldoon's own admission that he looks for the next rhyme: 'Because he makes such demands of words, they end up leading him into strange places.' He also opens up for the possibility that Muldoon is 'a rare poet who stays in virtuosic mode while discussing something grave.' Ian Sansom, in a hilarious review as sassy and jazzy in spirit as some sprite segments of Muldoon himself, thinks that Moy Sand and Gravel reads like 'the work of the impressionist Pound if he'd lived in New Hampshire, kept chickens, had sausage-sized fingers and taken to writing poems about roads not taken.' He finds 'the usual lexicographical enthusiasms and oddities in the new book, and wordplay, and puns, and mysteries, and narrative confusion, and squash-ball sentences, and lyrics, and mini-epics, caracols, buffets, haiku, sonnets, Heraclitean flux, shape-shifters, terrorists, "characters" with crazy names, fabulous car journeys, and much praise for America and Armagh. And Moy, of course.' He, like most critics, elevates 'Cradle Song for Asher' as the pinnacle of poignant poetry in the volume with parental frankness and artistic candour: 'All I know is that there's not a parent who wouldn't wish they had thought the thought, or a poet who wouldn't wish they'd written it.' He states of

6 Longley, 'Twists and Turns: Paul Muldoon's Moy Sand and Gravel,' 65.

7 Sean O'Brien, 'Memories Are Made of This. Moy Sand and Gravel by Paul Muldoon,' The Sunday Times, 26 January 2003, 48; Allison, "Everything Provisional". Fictive Possibility and the Poetry of Paul Muldoon and Ciaran Carson.'

8 Tom Payne, 'Four Ostriches and an Orange. Paul Muldoon's Moy Sand and Gravel,' The Telegraph, 9 November 2002, http://www.telegraph.co.uk/culture/4729277/Four-ostriches-andan-orange.html, accessed 5 January 2019. 
the volume: 'Muldoon may be in love with the possibilities of language; Moy Sand and Gravel demonstrates that he is also a poet in love with the possibilities life. ${ }^{9}$ Robert Macfarlane notes the volume's rhyme and language, and commends the seriousness: 'Muldoon's books, indeed, can often seem like rehab centres for language ... Decryption is a word that catches the prevailing mood of Moy Sand and Gravel, suggesting as it does both a decoding and a concern for the dead. ${ }^{10}$ Macfarlane sees a clear connection between the volume's language and its radical significance. He notes how the poetry shows a 'deep mistrust of dogma' and 'profound antipathy to the doctrinaire', and 'has made both an ethics and a poetics out of incertitude,' and retains a 'vital dimension of ethical seriousness.'11

Most reviewers explain how Muldoon's perpetual language engagement enacts seriousness and ethical depth. These reviews do not share Elmer KennedyAndrews doubt about 'how seriously we should take anything Muldoon says,' or his question about 'to what extent is he merely a highly inventive but emotionally evasive joker playing a slippery, virtuosic game of words and rhymes and allusions?'12 Astonishingly, many of the same reviewers, in spite of their astute critique, fail to see the novelty in Muldoon's language in Moy Sand and Gravel. Sansom states 'There is really nothing new here' and Quinney announces that 'the poems in Moy Sand and Gravel don't differ in kind from his previous work.' Bill Raglie argues that 'it still seems more of an extension of Hay than a distinctly new step.'13 Sure, Muldoon hones his linguistic edge, but these critics fail to see new orientations in Muldoon's ways with language.

Muldoon's investigations of the sentence are the fulcrum of this volume, which follows a more constructive than deconstructive direction. The linguistic shift to concentrated interest in sentence and syntax from previous immersions in lexicon, grammar, plots and play is very noticeable. In Moy Sand and Gravel the sentence appears as the linguistic unit against which other matters of language and content are balanced. This pivotal point in his poetry at the turn of the millennia appears as random and arbitrary as so many other

9 Ian Sansom, 'Awesome in Armagh. Moy Sand and Gravel by Paul Muldoon,' The Guardian, 2 November 2002, https://www.theguardian.com/profile/iansansom?page=8, accessed 5 January 2019.

10 Robert Macfarlane, 'High and Dry in the Flood. Paul Muldoon's Moy Sand and Gravel,' Times Literary Supplement, 11 October 2002, 24.

11 Ibid.

12 Kennedy-Andrews, 'Introducing Paul Muldoon: "Arbitrary and Contrary”,' 5, 17.

13 Bill Ragalie, 'Paul Muldoon's Latest: A Master Poet Writ(H)Es Again,' The Mac Weekly 95, no. 6 (2002), http://www.macalester.edu/weekly/101802/arts3.html, accessed 24 February 2019 . 
linguistic pin points, and as powerful, but a turn towards the sentence unit and the more constructive powers of language composition makes sense in the wake of the deconstructive excesses in Madoc and Hay. Sentences, like letters, words, points, plots, play and other Muldonic semiotics, assume alternative orders, multiple analogies and metaphoric multiplicity way beyond their syntactic functions. To Ireland, I, for example, displays in title, design and analysis the peripatetic and paratactic features of Muldoon's canonical recontextualisations from the Oxford pulpit, and demonstrates how Muldoon's crossings of linguistic and literary lines, geographical boundaries and identifications of self are characterised by linguistic leaps and associative alacrity more than canonical kowtowing, narratological conventionality and identitarian politics of nationality and selfhood. This title also shines with the importance of alphabetic singularity in Muldoon's audiovisual imagination and semiotic method, and it glistens with the processes of becoming: the subject, 'I,' is phonetically and visually inscribed at the inception of the nation, 'Ireland,' and, conversely, separated as a distinctive entity in a double-spaced position inside and outside the margins of collectivity and nationality: 'Ireland, I.' The placing of the preposition first in the sentence stresses movement: 'To Ireland, I.' The conspicuous omission of verb radiates unusual syntax and adds urgency to motion. Probably, the sentence highlights Gaelic syntax in the English language. Certainly, Muldoon's title acquires clarity in correspondence with Yeats's famous declaration in 'The Lake Isle of Innisfree:' 'I will arise and go now, and go to Innisfree,' and with Joyce's statement that the 'the shortest way to Tara is via Holyhead.' As a poetic parallel, Moy Sand and Gravel proposes a route to the poet's mother country, more specifically the rural region of his childhood and adolescence: Moy. Sand and gravel evoke elements of the earth as natural to the Moy, Armagh and Ireland as to Morocco, Arabia and Israel, geographical specifications that are all significant to the permutations and gravity of the volume; to its many alterratives. Sand and gravel, significantly, just like hay, suggest man-handled products as much as natural elements. They also constitute the primary elements in construction, and thus include in their allusiveness Muldoon's commitment to the creation of the best sentence.

Semi-self-referential verses in Moy Sand and Gravel affirm the attention to the sentence and present the potential emancipatory artistic powers of syntactic incarceration:

I was so long a prisoner

that, though I now am free, the thought that I serve some sentence is so ingrained in me 
that I still wait for a warder

to come and turn the key. (65)

These verses, a single sentence in 'Two Stabs at Oscar,' which meditate upon the fate and literature of Oscar Wilde, capture a claustrophobic sense of incarceration in the human condition alongside the religious miasma of eternal sin. The six-line sentence, however, also confesses to the inescapable importance of syntax to a language-conscious poet. The sentence presents a new segment of language which Muldoon subjects to inspection and attempts to liberate. This new orientation in Muldoon's poetry parallels his prolonged endeavour to liberate himself from the traditional mould of poetic forms - sonnets, sestinas, haikus, villanelles, narratives. It also complements the prolonged resistance to conventional ideas and forms, and to the functions phenomena of language that he has so far conducted throughout his career. Such anti-establishment animus appears as radical and aporetic as any deconstructive drive to critique Western metaphysics in a language that is predicated upon the very ideas it seeks to criticise. Muldoon's engagement with language implies larger contexts of change and consequence beyond the poem and the page. They are directed towards a future beyond the closure of the present. The imaginative quest for the articulation of unknown futures requires types of language and poetry that are in continuous motion towards the creative and the new. The established tends to confirm the status quo. Edna Longley is less convinced in her review, but points out the same potential in Muldoon's 'radical linguistic politics' 'because he continuously implies the norms from which his structures deviate or which they criticise.'14 Adlinguistically, the sentence in 'Two Stabs at Oscar' echoes uncannily Fredric Jameson's critical survey of structuralism in The Prison House of Language. It also, in its final word, refers directly to 'The Key' in Madoc, as a reminder of how Muldoon's poetry often sets new keys more then it offers the correct answers or the appropriate tools to solve a mystery. In the wider context of intratextuality and broad poetic preoccupations, this particular stanza forms a dialogue with 'Crossing the Line' (мтв, 17). The relations between the two, the sentence and the line, are as symbiotic and shifting as they are symbolic and supplementary. The sentence assumes priority in Moy Sand and Gravel.

The sentence is of key importance to language in its structuring of words, thought, syntax and grammar. The Oxford English Dictionary, one of or perhaps

14 Longley, 'Twists and Turns: Paul Muldoon's Moy Sand and Gravel,' 65. 
the source of language and poetic inspiration that Muldoon praises ecstatically, ${ }^{15}$ gives the following definition:
A series of words in connected speech or writing, forming the grammati- cally complete expression of a single thought; in popular use often such a portion of a composition or utterance as extends from one full stop to another. In Grammar, the verbal expression of a proposition, question, command, or request, containing normally a subject and a predicate (though either of these may be omitted by ellipsis). ${ }^{16}$

Muldoon explores and experiments with the concept of sentence throughout Moy Sand and Gravel. Scrutiny of the sentence involves entangled issues such as the balance between logic and language, thought and expression, and between line and sentence. Scrutiny of the sentence also involves such intricacies as word order, start, length, rhythm and prosody of the separate linguistic unit, and, of course, how the particular sentence relates to the preceding and succeeding sentences. Sentence construction becomes the main element in the poetic edifice of the volume. This attention to units of language and meaning beyond letters and words, plots and play, extends his incessant interest in language and gives the volume a more complete and coherent sense and structure. The sentence, nevertheless, serves a number of other symbolic purposes, as the stanza from 'Two Stabs at Oscar' illustrates so lambently. Its religious connotations can be traced at least to Peter Lombard's classic of mediaeval theology, The Four Books of Sentences (Libri Quattuor Sententiarum). Manifold understandings of the term as pointed saying, opinion, maxim, aphorism and apophthegm go further back. Derivatives, such as sententious and sententiousness, augment the term's meanings. Today the term 'sentence' also appears frequently in the general terminology of jurisdiction and punishment, as it does in the poetic realm, with specific reference to the literature and life of Wilde in the particular case of 'Two Stabs at Oscar.' These connotations of jurisdiction in the word 'sentence' also extend to Heaney's engagement with questions of justice in many of his poems, for example, 'Punishment' and 'Casualty,' and in many of his essays. In its understanding of structure and completion, sentence, in its many definitions, forms and functions, just like the various consistencies

15 Muldoon rejoices: 'My wife has just bought me the 13-volume $O E D$ as a present: I just love it. But I have little command of and facility in language. I'm constantly having to slow things down and examine what things mean.' AA, 'A Cat to Catch a Muse: Interview with Paul Muldoon,' 14.

16 The Oxford English Dictionary, http://www.oed.com/search?searchType=dictionary\&q=s entence\&_searchBtn=Search, accessed 17 April 2019. 
and mutabilities of sand and gravel, introduces a sense that construction tends to take priority over deconstruction in Muldoon's poetry from Moy Sand and Gravel.

The many implications of sentence - moral, existential, philosophical, linguistic - rest firmly on the syntactic traverses of the entire volume. Twelve of the forty-five poems in the volume unfold along a single sentence. 'Moy Sand and Gravel, 'The Braggart,' 'Beagles,' 'Whitethorns,' 'The Otter,' 'John Luke: The Fox,' 'Anthony Green: The Second Marriage, 'Eugenio Montale: The Eel,' 'The Breather,' 'A Brief Discourse on Decommissioning,' 'The Turn' and 'Cradle Song for Asher' range from four to thirty-six lines, and are contained in a single sentence quatrain, double sestets, sonnets or sestina. An even larger number of stanzas follows suit. Frequently, the sentence stretches across lines and stanzas. More often than not, the sentence stops in odd places; in the middle of the line, in the middle of the stanza. Rarely, the sentence coincides with the line. The sentence becomes another unit of poetic construction that forms dynamics of opposition to and cooperation with the line. How to deliver a sentence supplements the perennial poetic problem of how to turn the line. Muldoon has always been very aware of how the etymology and the tradition of the line comes from Latin versus, a term which stems from the ploughman turning the furrows as much as how a poet turns a line of poetry, or a term that means confrontation: against.The start, length and finish, the prosody, enjambment and volta, and the form and feature of genre and stanza shine forth in the variety of verses already on display in his debut collection New Weather. 'Blemish' in Mules presents the first one-sentence poem. 'Crossing the Line' (мтв, 17) epitomises Muldoon's consciousness of the complexities of the sentence. How a sentence hosts the lines (and stanzas), how it provides a longer syntactic measure for many of the same established poetic features, and how the sentence gains in wider symbolic significance, presents a new creative chamber in the language of Muldoon's poetry. Sentences of all kinds occur. Unsurprisingly, he explores most sentences that are less travelled and he tends to resist conventional structure and order.

At least half of the poems start with subordinate clauses in an inversion of the ordinate and the dominant of sentence structure. Conditional, temporal and comparative clause types, frequently infinite, incite modes of uncertain alternatives, different temporalities and double dimensions with a sense of open-endedness and infinitude. One-sentence poems that start with a main clause often function as a balloon, an expansive framework for how much you can put into it before it bursts, which in Muldoon's case it does not. Other main clause poems can be of interrogative and dialogic kind, as in 'A Collegeland Catechism' and 'The Grand Conversation.' Imperative sentences tend to appear only in 'At the Sign of the Black Horse, September 1999,' as a sentential 
oddity with strong syntactic symbolism of totalitarian control. Sentences come in almost all shapes and forms of the syntactic system. They are all different. They all exude premeditation. They also, however, mark a noticeable shift towards cogency, coherence and synthesis. Muldoon's attention to sentence over line, phrase and smaller syntactic units, not to mention alphabetic atomism and lexical mining, shifts emphasis towards construction in his poetic career. The linguistic framework Muldoon has imposed upon his own art, the sentence, also adds energy to his own creativity. His concentration on the sentence requires readers to sharpen their interpretational acuity. His profound scrutiny of sentence and syntax also holds radical implications for underlying structures in other artistic, social and political contexts. In addition to these general observations, each specific sentence, curve and coil serve their own points and purposes within the singular poem.

Many of the Muldonic language poems in Moy Sand and Gravel - 'Tell, 'As,' 'On, ' 'Famous First Words,' 'The Grand Conversation,' 'A Brief Discourse on Decommissioning,' 'At the Sign of the Black horse, September 1999' - radiate the importance and position of language. Other poems in the volume with less linguistically effervescent titles sometimes prove even more novel in Muldoon's look for the next rhyme.' His novelty also shows in his search for the next alphabetic trick, in his hunt for the next lexical beast and, particularly in this volume, in his drive for the new syntactic turn. 'Hard Drive,' a scathing and humorous multi-clichéd sonnet on the cultivation of grievance in many camps, 'keeping that wound green' (3), forefronts in the first poem the linguistic innovation upon which thematic concerns are predicated. The evident lexical and formal assurance in this exquisite three-sentence sonnet indicates the volume's metatextual meditations. A round trip in Northern Ireland, especially its borderlands, presents with love and joy and phonetic relish a number of places: 'Seskinore,' 'Belleek and Bellanaleck,' 'Derryfubble and Dunnamanagh and Ballynascreen' - a gazette of geographic precision and palatal linguistics. Heaney's dinnseanchas, place-name poems, lurk in the hinterland, as do Muldoon's own contentious poems in this genre. Sean O'Brien acknowledges the poem's far-reaching political implications: "Hard Drive" is surely "political" in its concern for what happens to language in the mouths of political sects seeking to perpetuate grievance. ${ }^{17}$ This unconventional opening sonnet certainly administers a strong antidote to the pestilence of festering political grievance. The catalogue of clichés suggests how reproduction of dead language abets the harbouring of old wounds, prolongs traumatic memory and hampers renewal by foreclosing resolution in the repetition of formulaic and outdated rhetoric.

17 O'Brien, 'Memories Are Made of This. Moy Sand and Gravel by Paul Muldoon,' 48. 
A concern for clichés and dead language and how they work and why, is surely of pressing interest and relevance. These verses are indicative of the lexical boreens, the poetic byways, cultural back roads and digital highways with which the book engages. Recourse to well-grounded lines of language keeps conventional trains of thought on track and facile rhymes (at least in Muldoon's repertoire) direct easy combinations and unproblematic fusions. Facile and outmoded, the clichés also capture inflexible retrospection and they create a counterpoint for the subsequent linguistic innovation and refraction of established views of the past in numerous succeeding poems. Self-consciously, the verses play on the difficulties of poetic composition and, contextually, on the problems of codes and communication, and on the sending of messages to the right addresses. One such addressee is the pool of car and drive poems, well steered by Heaney. ${ }^{18}$ Another is Muldoon's own poetry. ${ }^{19}$ Where annals and TV-channel switching suggest organising templates to The Annals of Chile and 'Yarrow,' 'Hard Drive' indicates the PC as a metaphor of memory and semantic processing. In this context, the clichés occur as macros in a programmed language to reveal their rigidities and possibilities, a parallel and provocation to the limits and liberties of poetry. The PC, the technical revolution of our era, one of the paradigms of postmodernism and the ultimate system of binary codes, reigns as a medium and (for some) a menace to the arts in a new millennium. The three sentences in this poem, which run across lines, quatrains and couplets, can be seen as a numerological overriding of these implied binaries, and one can discern, in their careful construction, an affirmation of the importance of the sentence in this volume. Their subordinate structure indicates general intent to reverse ordinary order, and introduces the sentence as a new arena for Muldoon's fascination and experimentation with language. In Moy Sand and Gravel Muldoon resists and crosses the structures of the digital medium with creativity and circumspection. 'Hard Drive' signals strongly in the first poem that the routes and rotes of poetry constitute one of the main roads down which this volume travels.

A number of poems takes the implications of 'Hard Drive' in different directions. 'Unapproved Road,' the next poem, connects with 'Hard Drive' in troubling road imagery and by exploring many of the initial poem's implications. Originally commissioned for Logue's The Border (2000), the poem takes its title

18 For a critical survey of Heaney's car imagery, see Medbh McGuckian, Horsepower Pass By! A Study of the Car in the Poetry of Seamus Heaney, ed. University of Ulster (Coleraine: Cranagh Press, 1999).

19 Some of Muldoon's car and drive poems are 'Good Friday, 1971. Driving Westward' ( $N W$, 23), 'Ireland' (WBL, 19), 'The Sightseers' $(Q, 15)$, 'The Windshield' (Mag, 34), 'Wayside Shrines' (Mag, 110-120). 
directly from the official term for the many blockaded roads and destroyed bridges preventing unauthorised border crossings between Northern Ireland and the Republic during the conflict. ${ }^{20}$ The title's associations extend further and the poem couples Republican and Arabic issues at a time when xenophobia contemporaneously challenged the tradition, culture and mindset of Northern/Ireland, America and elsewhere. In a separate intervention, Muldoon has stated that he is 'very suspicious of a worldview where we equal our passports.' He also admits to fleeting national attachments: 'I've had a UK passport along the way too...but my primary affiliation is with Ireland, where Ilived for the first 35 years. ${ }^{21}$ These border poetics take place in a poem that negotiates language, sentence, sestina and terza rima, revisits Muldoon's own border land poems, not least 'Cows' $(A C, 33)$, and interacts with the many frontiers of Heaney's poetics, especially from The Haw Lantern. The poem also presents a conjunction of the many sentences - interrogative, complex and dialogic more than simple, declarative and imperative - that are later brought into singular focus. Perhaps the lithe one-sentence 'Eugenio Montale: The Eel,' which writhes in the sea of translations and the eel currents between Heaney and Muldoon, captures most suitably in image and syntax the challenge of turning the sentence. ${ }^{22} \mathrm{~A}$ reading of some of the other poems illustrates the significance of the sentence in this single poem, and hints at its many hermeneutic possibilities in others.

'The Turn,' a Muldoonesque sestina, reverts to and diverts from familiar Muldoonian terrain in theme and technique. Muldoon's evocative and wonderful meditation upon the changes and continuities of life are presented in a persona's convoluted retrospection upon the imagination and reality of his life. This journey unfolds as a camel ride across the shifting sands of deserted lands. A very suitable ergative syntax stresses shifting moods and transitions.

$20 \quad$ Paddy Logue, ed. The Border: Personal Reflections from Ireland, North and South (Corcoran, California: Oak Tree, 200o).

21 Kilroy, 'Transatlantic Poet. Paul Muldoon's Moy Sand and Gravel,' 7. Famously, Heaney, who was known to have declined sponsorship from the British Council, protested against being included in Morrison and Motion's Contemporary British Poetry, and brandished his Irish passport in 'An Open Letter.'

22 Slippery eels suggest a very lithe metaphor for sentence. For eels in the interpoeticality and semiotic seas between Muldoon and Heaney, see Heaney's 'A Lough Neagh Sequence' in Door into the Dark (26-33); 'Widgeon: for Paul Muldoon' in Station Island (48); 'Settings xvii' in Seeing Things (73) and 'Eelworks' in Human Chain (28-32). Muldoon attends to eels and Heaney's poetry, in 'The Briefcase' in Madoc (12), 'Eugenio Montale: The Eel' $(M S G, 58)$. Fran Brearton states that 'those Lough Neagh eels have had as many critical lives as a cat.' Brearton, 'For Father Read Mother: Muldoon's Antecedents,' 50. 
Two temporal clauses capture from the very start convolutions of time, family contentions and the confluence of fiction and fact:

In those days when the sands

might shift at any moment, when his mother might at any moment lay into him, he thought nothing of getting up half-way

through a story about the Sahara, (69)

'The Turn' is another tour-de-force in Muldoon's repertoire of syntactic sprezzatura and memorable pathos that goes on with turns and returns, from the past to the present, through recurring memories of the individual in the larger circles of human devastation and desolation, to the final denouement in the envoi:

\section{back through the sands}

on which lay the bones of thousands

of his countrymen, through the sand-pile that was not at

all reminiscent of the Sahara,

having him turn back inside to pick up his own sentence, to hear himself out. (70)

The title, 'The Turn,' places the poem amidst a plethora of associations and self-reflexive linguistic signpostings. For all its associations of rotation, twist, change, deflection, curves and bends, 'The Turn' also points directly to its own syntactic composition and poetic creation. Muldoon's one-sentence sestina offers an observable turn in the tradition of the thirty-nine-line format. To continue a single sentence in thirty-nine lines and to incorporate thirty-nine lines in a single sentence, make a change in creative challenge for the master of contemporary sonnet de/construction. The reader and critic will have to bend her mind, too. The thirty-nine line one-sentence sestina engenders its own turning of lines, stanzas and chimes in a virtuoso display of sustained connectivity. Its creativity within the confines of a strict genre structure turns out to be a selffulfilled prophecy of the introvert confession in the earlier poem 'Two Stabs at Oscar:' 'I serve some sentence' (65). Its melancholic vivaciousness and expansive temporal vistas tend to commute the short moment and severe sentence of judgement in 'Now, Now:' 'Life is indeed no more than "a misprint in the sentence of death"' $(H, 23)$. Its sense of extension, construction and synthesis departs from the stops, leaps and lacunae in 'Crossing the Line' (мтв, 17). 
The carefully constructed verses in the beginning continue throughout the thirty-nine lines and seven stanzas to compose in a single sentence a unity of past and present, of family and of experiences in literature and life. Transmutations of words and chimes combine with the ergative syntax to emphasise change and continuity: 'Sahara' and 'Saahaara,' 'scent' and 'sentence,' 'twists and turns,' 'ergs and regs' (69-70). Rotation of rhymes stresses the sense of remembrance, repetition and reorganisation. As a biography of a boy and a young adult's imaginative life, the poem's reminiscences divert from historical facts to imaginative, and an imaginative experience that ranges from A.E.W. Mason's adventure novel The Four Feathers (on loyalty and love in the Mahdist war in Africa just before the turn of the 2oth century) into a large playground of Muldonic intratextuality in its many direct references to 'Ned Skinner' in Mules, and to his many previous mother poems in its mixture of childhood adventure and maternal admonitions, and countless indirect ones to Madoc ('Saahaara, 'Saahaara` and expedition in unknown territory), 'Quoof' (a lovemaking couple in an unidentifiable 'hotel room') and to this volume's 'Unapproved Road' (in desert landscape and camel riding) - to mention just some intratextual parallels. There are few limitations to the many sifts and shifts between this poem and the numerous other poems in Muldoon's artscape, whether by theme, content, form, line or sentence. To the extent that these all lie in the past, just like the persona's memories, a complex usage of verb tense integrates forcefully the past with the present. The use of the third person pronoun, relatively rare in this self-revelatory type of poetry, creates a definite distance to everything that is referred in the poem. The number of lines, 39, in view of Muldoon's general attention to numerology and especially in view of the significance of the 45 stanzas and the year 1999 in the final poem, also creates some distance as the number points to the drastic changes in 1939. Thus, a temporal vacillation between the personal and immediate and the historical and distant parallels the unusual presentation of what appears private and personal by a third person persona. 'The Turn' emphasises in title and form both drastic changes and iterations in life. Its syntax also directs in form and language new tendencies towards flexibility, cohesion and construction in Muldoon's own poetry, which previously often tended towards disjunctions, abruptions, impasses. 'The Turn' shows how Muldoon's preoccupation with the sentence reveals another side of his poetry, as well as another glimpse into the mysteries of how past memories bear upon present life.

That premeditated choice and inspection of a specific sentence structure gives life and form to a whole poem, is clearly seen in 'A Collegeland Catechism.' Muldoon's concentration on sentence, in all its syntactic functions, 
turns and relevant analogies, creates the poem, articulates its themes and content, and enters into a dialogue with religious, poetic and political discourses. In 'A Collegeland Catechism' interrogative sentences develop in significance from syntax to serioludic questioning and critique of religious dogma and philosophical hegemony.

Which is known as the 'Orchard County'?

Which as the 'Garden State'?

Which captain of the Bounty

was set adrift by his mate?

Who cooked and ate an omelette

midway across Niagara falls?

Where did Setanta get

those magical hurley balls

he ram-stammed down the throat

of the blacksmith's hound?

Why would a Greek philosopher of note

refuse to be bound

by convention but live in a tub

from which he might overhear,

as he went to rub

an apple on his sleeve, the mutineers

plotting to seize the Maid of the Mist

while it was still half-able to forge

ahead and make half a fist

of crossing the Niagara gorge,

the tub in which he might light a stove

and fold the beaten

eggs into themselves? Who unearthed the egg-trove?

And who, having eaten

the omelette, would marvel at how the Mounties

had so quickly closed in on him, late

of the 'Orchard County'

by way of the 'Garden State'? (15-16) 
'A Collegeland Catechism,' by taking the interrogative sentence as its point of departure, belongs to the catalogue of Muldonic language poems that stay in the memory and develop their hermeneutic plenitude from a specific language phenomenon, such as lexical scritiny in 'Bang' $(M, 50)$, neologism in 'Quoof' $(Q, 17)$, line in 'Crossing the Line' (м тв, 17), acrostics in 'Capercaillies' (Mad, 6), narrativity in 'The Plot' $(H, 15)$, homonymy in 'They that Wash on Thursday' $\left(H, 5^{2}\right)$, manuscript corrections in 'Errata' $(H, 88)$, different sign systems in 'Rune' $(H, 96)$, language puzzles in 'Riddle' $(H L, 76)$, digital signs in '@' (Mag, $74)$, all his abecedarian poems and all the language poem in this volume. Experiments in rhyme drive all these poems. They appear like letters in a word, words in a clause and clauses in a sentence in Muldoon's continuous examination and critique of the underlying structures and the larger systems of language, such as post-structuralist philosophy in Madoc and sentence in Moy Sand and Gravel. This poem reads as a primer in wh-questions and a study in clause and sentence structure. All the interrogative sentences represent a universal quest for knowledge and understanding that ranges from childlike curiosity and trivial pursuit to religious quandary and philosophical inquiry. A pedagogic progression in level of difficulty characterises the questions. Accessible and intellectual humour, cross-continental exchanges of history and culture and destabilising inquisitions characterise these verses, which, at least by Muldoon's own standards, verge on deliberate doggerels, and unsettle certainties. The answers to Muldoon's recusant gallimaufry of popular and erudite questions from childhood, academic circles and religious precincts generate further conundrums. Armagh, New Jersey and Captain Bligh, the likely answers to the first three questions, implicate autobibliographical scrutiny in a mutinous crossing of continents, denominations and cultural categories. Another correct answer is the nineteenth century Niagara funambulist, Jean François Gravelet, whose artistry and Western contortions balance aesthetic avoirdupois and individual courage. 'Form is a straitjacket in the way that a straitjacket was a straitjacket for Houdini,' Muldoon explains with his characteristic zeal for enthralling tropes of poetry. ${ }^{23}$ This assertion of liberation from formal constraints - whether genre, stanza, line or sentence - defines precisely one aspect of the poet's self-evaluation of the mental processes of creation. Gravelet lucidly depicts the challenges of walking upon a self-constructed sentence and upon all the lines in sentence, stanza, canon and contexts. This image of the poetic artist offers a subliminal gloss on 'Crossing the Line' (мтв, 17), the intratextual reference to this volume's many single sentence poems. Jokes on a poet's position in poetry and on the policies of publishers and universities

23 Kilroy, 'Transatlantic Poet. Paul Muldoon's Moy Sand and Gravel,' 7. 
are in the balance too, just as the cost of religious doctrines, political rhetoric and historical conflict resonate in the bottom line and final sentence.

Born in Saint Omer, the Catholic stronghold in Northern France, Gravelet, a.k.a. Charles Blondin, 'The Little Wonder, 'The Prince of Manila,' performed at Niagara Falls and the Crystal Palace, toured England and the continent, gave his last performance in Belfast and died peacefully in retirement in London. In 1859-6o the French daredevil mesmerised the attending crowds and provoked the nature purists by his artistry in crossing on a tightrope the Niagara Falls on several occasions, each time with a new trick: blindfolded, on stilts with a wheel barrow, with his agent Aeneas-like on his shoulders - once he made an omelette midway. He caused public commotion and uproar, and several times had to endure public demands for his arrest. Gravelet's performance points to acts of prosody, to the sure-footed tricks of line-dancing and to the elevated, risky, controversial and earthbound position of a poet; a very suitable aerialist parallel to the well poised quips, queries and quests of 'A Collegelands Catechism,' and to the unapproved foci of Moy Sand and Gravel. Gravelet presents a figure of artistic altitude, linguistic equilibrium and crossings of all kinds that swerve with the risks and fanciful ideas of falls. His name, Gravelet, rhymes with the question's 'omelette,' as if the figure appears from or in response to a quest for sonic similitude: rhyme delivers reason. Gravelet, close to an anagrammatic pun on elevate, plays on the gravity of the solemn and the serious, and links up with the book's title and its intermittent diminution of the grand and the grave. Gravelet signifies without words and beyond mimesis. His irrational performances question logic and language in profound acts of humanity: only man would conduct such functionless artistry as line-balancing. Semiirrational, speechless and gestural acts by an expatriate artist seem a striking parallel to a funambulist poet, i.e. Muldoon, who often balances the modernist modes of silence, exile and cunning with the postmodernist modes of language scepticism, marginality and reflexivity, and who tries to trace the relations between line and sentence in contexts beyond the poem.

Gravelet signifies ideological relativism and linguistic discursivity. More than representing abstract intellectualism removed from reality, or a signifying system totally detached from fundamental functions, he walks the tightrope of postmodernism: rapid movements back and forth upon temporary attachments to opposite precipices in a transient mastery of gravity and levity. Any static intellectual stance that fails to respond with agility to its climate and conditions - fundamentalisms of all categories - increases the risks of falling into abeyance, if it has not already done so. That such eventuality relinquishes the possibilities of propositions, logical assurance and referential affirmativeness does not discount the intellectual vitality of such apparently 
unaccountable acts, or detract from their imaginative daring and significance. As a procursive and recursive equilibrist on a line, the funambulist illustrates the unstoppable processes of signifiance, the alignments of discourses and the temerity to act without identifiable points of origin. That such semiosis at times appears absurd, anarchic and morally condemnable does not deprive its elevated acrobatics of significance and social effect. Poets, thinkers, writers of the postmodern perform on a tightrope of spliced significance; the slightest stumble or lapse will precipitate the sentences in question to veer towards the outmoded, the modern and the monological of undifferentiated and noncontextualised systems, ontology, metaphysics or sheer opinion.

As ever, Heaney's critical and creative idiom provides one parallel for Muldoon's lines. 'A Collegleland Catechism' is poised as a response to Heaney's critique of Muldoon as a poet 'whose swerves away from any form of pokerfaced solidarity with the political programs of the Northern Catholic minority (from which he hails) have kept him so much on his poetic toes that he has practically achieved the poetic equivalent of walking on air. ${ }^{24}$ Muldoon's poem also communicates directly with Heaney's poetry. Such poems as 'Punishment' in North and 'Casualty' in Field Work grapple with soul-searching questions of murder, social justice, national self-determination, metaphysical justice and individual responsibility. Heaney punishes and purges his soul in homely and homiletic verses in Station Island. Perhaps the Nobel Laureate's 'Whatever You Say Say Nothing' in North charts most mordantly the minutiae of calculated muteness in recent Northern Irish poetry. Running somewhat in contracts, that poem also postulates the primacy of artistic articulation:

I believe any of us

Could draw the line through bigotry and sham, Given the right line, aere perennius. (North, 53)

'Freedman' in the same collection confesses to poetry as a means of liberation from religion and suppressive structures. If the critical controversy in the wake of North, Muldoon's interpoetic responses included, especially in The More a Man Has the More a Man Wants $(Q, 40-64)$, suggests that Heaney's collection did not manage to disengage art from communal commitment, religious inclinations and political encroachments, Heaney's quest for right balances recurs in The Spirit Level, a prominent counterweight to Moy Sand and Gravel. The duality of Heaney's image and the levity of the title poem suggest new points

24 Heaney, The Place of Writing, 52. Scammel expresses a similar view in 'Mid-Air Street? Review of Meeting the British by Paul Muldoon,' 144-146. 
of equipoise, new notes in Heaney's solemnity that might respond to Muldoonian stratagems. Nevertheless, Heaney is never in doubt of which way to tilt the scales if the weights cannot be evenly distributed. 'Weighing In' proportions systems of estimation by placing a $56 \mathrm{lb}$. weight, 'a solid iron unit of negation,' on a weighbridge as a metaphor for personal aggravation and social inequality. Impartiality, however, has its limits:

Two sides of every question, yes, yes, yes ... But every now and then, just weighing in Is what it must come down to, and without Any self-exculpation or self-pity. (The Spirit Level, 18)

In this volume, 'Eugenio Montale: The Eel' adheres to the familiar imagery of their antithetical amicability by contrasting equipoise and altitude with the pelagic and lacustrine in what amount to lithe exchanges of line and sentence between the two poets. A dislocated voice in 'The Gravel Walks' of The Spirit Level echoes Heaney's judgment of Muldoon's airiness when it (self-) admonishes without address:

So walk on air against your better judgment

Establishing yourself somewhere in between

Those solid batches mixed with grey cement

And a Tune called 'The Gravel Walks' that conjures green. (139)

Muldoon responds to a letter by 'Doctor Heaney' in one of the poems in The Prince of the Quotidian:

the great physician of the earth

is waxing metaphysical, has taken to 'walking on air';

as Goethe termed it, Surf and Turf. (14)

Muldoon's Gravelet and the air ship of Heaney's Clonmacnoise poem in Seeing Things, 'Lightening viii' (62), offer two summits in their companionship of letters and in their use of metaphors of elevation. Furthermore: is the she goat, which is 'walking on air, / bounding, vaulting, pausing in mid-career', in Muldoon's 'The Mud Room' $(H, 3)$ possibly a figure of Heaney or himself? Does Heaney pass sentence on their lofty lines in his Nobel Lecture: 'For once in my life, I am permitting myself the luxury of walking on air'? ${ }^{25}$ Heaney's poetics

25 Heaney, Crediting Poetry, 11. 
provides one of the points of reference for new publications by Muldoon. Muldoon's evolving poetics provided for many years one the reference points for Heaney's publications. Yet, despite mutual concerns and similar imagery, they still approach the balances of poetics, religion and politics differently. Nevertheless, they share a sincere concern for righteousness, a concern symbolised by Diogenes in both Heaney's title poem to the The Haw Lantern and Muldoon's 'A Collegeland Catechism.'

Showmanship on a line stretched between poles presents the importance of the imaginative in the bridging of gaps. Unpredictably, cultural artefacts and events can contribute to conciliation in avenues not available to pragmatic politics and economic egalitarianisation. The unification on stage of the UUP leader, David Trimble, and the SDLP leader, John Hume, by the means of the lead singer of Dublin's world famous rock band $\mathrm{U}_{2}$, Bono, at the concert of Northern Ireland's top rock group, Ash, at the gleaming new Waterfront Hall in Belfast on Tuesday 19 May 1998 in an impromptu publicity coup for pro-peace accord campaigners by a rock celebrity three days prior to the referendum on the Good Friday Agreement offers a very mundane manifestation of such lofty truisms in the recent history of Northern Ireland. ${ }^{26}$

Gravelet is only present in the poem as an implicit response to the rhetorical questions, as are Cúchulainn, Diogenes and the articulation of canine conceits. The Cúchulainn figure is called into play by rhyme and responses to a set of extraordinary questions that might derive their main motivation from this enigmatic figure in the first place. Doggy style treatment of presence and purity - poetic, national or religious - plays on the hound of Cúchulainn, the Canadian colloquialism for an Irish Roman Catholic as dogan, the cynicism of Diogenes and a variety of other idiosyncratic doglegs. Muldoon's many crossings of line and sentence in this idiosyncratic catechism also call into question issues of religion, arts and poetry.

'A Collegeland Catechism,' as the title indicates, also crosses geographical and patriotic lines. The arrival in Armagh by way of New Jersey echoes a Joycean re-route to Ireland from abroad that refracts opinionated insularity and conducts a deliberate cracking of internal codes and self-contained life, a re-routing that is not unlikely to instigate censorship from various camps. Questions and answers, again, incessantly indict Muldoon's previous poetic engagement with religious orthodoxy and canine whims, and with Gaelic mythology and Western philosophy, and it is an example of Muldoon's

26 Suzanne Breen, 'Bono's Unusual Support Act Wins Standing Ovation,' The Irish Times, 20 May 1998, 1. See also 'U2's Bono Helps Promote Belfast Peace Agreement,' cNN Interactive. 
enigmatic linkage of disparate poems that the atmosphere of interrogation, police pursuit and textual reduplication recalls the text-driven terrorist tale 'The More a Man Has the More a Man Wants' at the end of Quoof. Furthermore, the moral imprimatur of 'A Collegelands Catechism' follows logically from the erotic innuendo and dressage of lines in the preceding double sonnet, 'The Whinny.' 'Beagles,' the succeeding poem, defaces the alternative catechism's canine conceits. Formal? Clever? Abstruse? No doubt.

Still, 'A Collegelands Catechism' confronts religious predeterminism and processes of cognitive foreclosure. As the title specifies, these verses question the religious didacticism and juvenile instruction in Muldoon's birthplace, Collegeland, a rural area in County Armagh close to Moy, which was formerly the property of Trinity College, Dublin. Some of the structures of belief and education that form individual lives in problematic ways, with regard to which this poem raises questions, are formerly visited in such poems as 'The Bishop' and 'Anseo' in Why Brownlee Left. They also remonstrate against doctrines of confession, concepts of original sin and methods of rigorous education. This remonstrance against fundamental tenets of Catholic theology is no oblique expression of subversive Lutheran Protestantism: 'A Collegelands Catechism' responds to and displaces religious logocentrism, particularly the dogmatic Lutheran theology, church and catechism, in favour of a secular relativism. Such destabilisations of teleological dialogue also extend to Socratic dialogue in higher education. The poem's questioning into being of Diogenes evokes the life and stoicism of the Greek philosopher who is notorious for dogging Antisthenes' footsteps, for publicly mocking Alexander the Great and the upper echelons of society, and for disputing the teachings of Socrates and Plato. Interrogative sentences in 'A Collegeland Catechism' engender critical inquiry of religious doctrines and institutionalised philosophy.

Formally, the stanzaic chiasmus of this double sonnet with no volta mirrors elision of a distinctively divisive central line: line and sentence are elegantly balanced and integrated. Subdivided into seven quatrains, the composition incorporates mythic and mystic numerology in yet another example of how, in sonnets, Muldoon really ex-cells. In these shifting contexts, it can be no accident that Muldoon chose 'A Collegelands Catechism' for a virtual presentation on the internet for a number of years. Where the potentials of play in 'The Plot' in Hay appear to be arrested by their transcription on paper, hypertextuality realised the many virtualities, lexical links, imagined combinations and the flow and stream of in these lines and sentences. ${ }^{27}$ The digital version of the poem seemed a bold attempt to balance the art of poetry in the crossing from

27 The animated enactment of 'A Collegeland Catechism' figured for some time on Paul Muldoon's home page, but has since been taken down. 
one medium over to another, from the traditional page to the digital space. Thus, the translineality and many crossings in and of 'A Collegeland Catechism' make this double sonnet a very peculiar poem, a poem in which the interrogative sentence develops its own dynamics to prick and to poke the great and the small of the human condition.

Whereas 'A Collegeland Catechism' develops its heuristic questioning from interrogative syntax, 'The Grand Conversation' enacts its meditations upon encounters between cultures and individuals through the language of discourse and dialogue. Whereas the first tends to splinter grand conversations of religion, politics, arts and language into a gamut of questions, the second tends to turn quotidian talk towards the higher spheres. A major question nevertheless emerges: what is this grand conversation? These two poems overlap by other means too. Just as Muldoon's catechism with no given answers suggests a metaphysical vacuum to man's quest for meaning, the titular promise of grand importance places the quest for meaning in life between individual life and its larger contexts. 'The Grand Conversation' takes the form of a dialogue between She and He. The two interlocutors compare and contrast their personal religious, historical, social and political background - with a glance to linguistics too, of course. The two speakers could be clergy, politicians, activists, or your woman and man on the street. They could also be man and wife. She comes from a Jewish community in a Polish-Russian border town, 'Korelitz / where they grew cucumbers / and studied the Talmud;' He comes from 'the mud / of mangold- and potato-pits' in 'Comber,' County Down, Northern Ireland (41). They both share a background of oppression and persecution and the hardships of emigration in America. Both persons overlap in background with American writer Jean Hanff Korelitz and her husband Paul Muldoon. They both speak in well-defined strong sentences, a series of serious statements far removed from daily chit-chat, as the title so surely proclaims. What is the grand conversation? The title evokes the high rhetoric of ideas and - isms, and of larger than life terms: religion, nation, class, gender, language. One of the conversations is obviously how the individual tackles her or his background - a story which is left out of this grand debate. Another is certainly gender balance in this poem where prioritised position in the dialogue, mathematical number of lines and exact metrical measures in their shared stanzas emphasise the idea of equality. A third is cultural encounters. Most of Muldoon's poetry refuses to be reduced to the singular and the selfsame; his poems incorporate the other and the plural and the elsewhere. This poem and Moy Sand and Gravel enhance the staple juxtaposition of Northern/ Irish and Amerindian history in Muldoon's earlier volumes with that of the Jews. In this volume, his cultural poetics of the private and the public 
dimensions are often enacted along the lines of the Jew and the gentile. 'The Goy from the Moy' (78) remembers his ancestors, the 'Irish schlemiels' (81), while living with the people who 'came from Korelitz... and studied the Talmud' (41). Nevertheless, the subject matter transcends the private while often retaining a deep personal tone. The cultural confluence is no facile trope as the Jewish tradition interacts with the Arabic and American - and, no surprise, Muldoon keeps undermining its pieties with sardonic chutzpah. 'The Grand Conversation,' however, in poetic form, keeps a tight balance between rhetoric and ridicule. The tone is serious and the backgrounds to which the poem refers - the destruction of the Jewish community in Korelitz and the conflict in Northern/Ireland, the fate of Irish and Jewish immigrants in America - utterly tragic. These verses capture the pathos of other poems, for example 'The Stoic' and 'The Loaf.' Yet they also belong to the volume's continuous conversation about the wounds and enduring hardships of trauma, the hard drive that runs in the volume from 'keeping that wound green' in the initial poem via the many heart-rendering poems of personal and cultural trauma, to the complexities of the final 'At the Sign of the Black Horse, September 1999.' 'The Grand Conversation,' in title and content, also retains a scrupulous awareness of language in its enactment of Lyotard's definition of the postmodern as 'incredulity towards metanarratives,' and of the postmodern condition as one in which the individual lives at the intersection of several narratives which are not necessarily communicable. ${ }^{28}$ Muldoon's poem obviously presents how two individuals live together at the cross-section of the metanarratives of religion, history, society, gender, violence, language. His verses are also resonant with a sense of control and forbearance in this condition that has frequently been associated with commotion and deconstruction:

\section{Between fearsad and verst}

we may yet construct our future as we've reconstructed our past and cry out, my love, each to each from his or her own quicken-queach. (42)

This sentence retains a personal focus of love and overcoming in the welter of larger discourses and difference. Language, in typical postmodernist fashion, is the medium without which our condition cannot be grasped, but the richness and range of language also enlarge our condition. 'Fearsad,' Irish local

28 Jean-Francois Lyotard, The Postmodern Condition: A Report on Knowledge, xxiv. 
name for sandbank that also gives name to the underground river Farset in Belfast, and 'verst,' Yiddish for verse, indicate the importance of language exchange in cultural encounters. Connotations of verse as versus, against and turning around, are also important here as a sense of one-upmanship characterises the conversation. The whole poem also changes tense from past to future: the focus on the past can easily become a self-fulfilling prophecy for the time to come. Sand and verse are not chosen at random: they are the metaphorical and poetic elements that make up much of Moy Sand and Gravel. 'Quicken-queach,' a Muldoonesque neologism and obsolete dialect for growth of bushes, adds a dimension of fantasy and melody to love and language. The poem ends on an allusion to the biblical Absalom, King David's son who rebelled against his father and was caught and killed in a tree while fleeing on his mule: 'his nag tugs at a rein caught on a snag' (42). The final verse hints clearly towards a tragic outcome for family life under political duress, an admonishment against the costs of prioritizing the larger discourses of power and religion over the values of the individual, a poetic parallel to 'incredulity against metanarratives.' A total number of forty lines might suggest an optimistic chance of a new beginning, in its numerological allusion to the forty years of Moses and the people in the desert before entering a new era in the promised land. The couple's conversation, which also includes declarations of love, takes the form of a dialogue, the space in language for exchange of philosophy, politics and love from Plato to peace negotiations and pillow talk - a space that reaches far beyond its own linguistic medium, and which is frequently under all kinds of threat. Muldoon's poem can, in the larger scheme of things, be regarded as a small response to The Clash of Civilization and the Remaking of World Order, the treatise by political scientist Samuel P. Huntington. ${ }^{29}$ In its literary contexts, Muldoon's poem connects directly with the dialogues of Yeats, and, intratextually, with a wide series of poems, most notably perhaps 'The Mixed Marriage' in Mules, 'The Mud Room' in Hay, and with 'A Brief Discourse on Decommissioning,' 'A Collegeland Catechism' and 'At the Sign of the Black Horse, September 1999' in this book. ${ }^{30}$ The sentence in 'The Grand Conversation' extends in forthright syntax and stanzaic solidity and

29 Samuel P. Huntington, The Clash of Civilizations and the Remaking of World Order (New York: Simon and Schuster, 1996).

3o Perhaps Muldoon's poem 'The Grand Conversation' responds most directly to the dialogue between he and she in 'Michael Robartes and the Dancer.' For other of Yeats's poetic dialogues that have paved the way for Muldoon's, see his exotic recasting of the ambivalences of marriage in the context of national romanticism, 'Anashuya and Vijaya;' the strife of royal combat and philosophical meditation in 'Fergus and the Druid;' the conflict of song and strife in the pastoral 'Shepherd and Goatherd;' views of literature in 'Ego 
navigates the many moral issues at stake in the poem. From a larger perspective, it is evident that the composition and content of the poem turn more towards synthesis and coherence than disunity and dissolution.

If the adlingual poems and 'A Collegelands Catechism' appear cold and clever in their cerebral cynosure, and 'The Grand Conversation' balances on a serioludic edge, 'The Loaf' and 'The Stoic' engage profoundly with more emotional human concerns without plunging into sentimentality. The primacy of commemoration in The Annals of Chile continues in this volume to offer extremely affecting poems that also excel in ingenious syntax and artifice. In fact, syntax and artifice may be said to strengthen their affective impact. An elegy to the Irish navvies, 'The Loaf' (47), is polished to perfection, and portrays with imaginative solidarity the dismal deprivation of the Irish canal diggers in New Jersey with a refined variation of one-line refrains that captures a poetic note of artistic distance and existential inclemency. While refurbishing the house, perhaps built by Irish navvies, the persona's tactile evocations unfold from his almost obscene attraction to a dark hole in the wall:

When I put my eye to the hole I see one holding horse dung to the rain in the hope, indeed, indeed, of washing out a few whole ears of grain

with a wink and $a$ wink and a winkie-wick.

And when I do at last succeed in putting my mouth to the horsehair-fringed niche I can taste the small loaf of bread he baked from that whole seed

with a link and a link and a linky-lick. (47)

A raw sensuality that inverts the clichéd anatomy of 'Hard Drive' reveals almost corporeal affinities with the dismal fate of Irish predecessors, affinities that are also comprised by the title's play on food for survival and the intellectual activity of an idler. Implications of self-aware autorial comparisons recall Yeats's meditations in 'Ancestral Houses' and echo the biblical verses: 'Bread of deceit is sweet to a man; but afterwards his mouth shall be filled with gravel;' 'Or what man is there of you, whom if his son ask for bread, will he give a stone.' These allusions evince sympathy and present an occasion for existential

Dominus Tuus;' the confrontations of 'Crazy Jane Talks with the Bishop' and the selfsearching of 'A Dialogue of Self and Soul' and 'The Man and the Echo.' 
self-evaluation. ${ }^{31}$ Transitions in the end from scatology to sanctification commemorate physical labour and artistic endeavour. This miracle of transubstantiation expresses compassion for victims of individual and communal destitution, and discloses human misery while at the same time it is illustrative of the uneasy poetic genesis the poet finds in this dark subject matter. The double affirmative of this aestheticisation is not necessarily comforting as the poem meditates upon a relatively unknown aspect of human suffering, and upon one aspect of the almost universal indifference to this suffering. The artistic act of overcoming ultimately confirms a dark and merciless universe. Sentence and line perfect the composition. Each of the five full-sentence stanzas starts with a temporal clause, 'When I,' and ends on the enigmatic and rhythmically varied one-line refrains. These refrains create artful dynamics of similarity and difference that are expressive of a genuine wish to connect a living artist's labour with the creativity and craft of past lives despite the passage of time. The particular feature of the one-line refrain, a close connection with the poetry of Yeats and MacNeice, and the urge for a home and a place to belong to, link this poem to the later 'Homesickness' (63-64), another masterpiece of the refrain. ${ }^{32}$ In its compassion for the Irish navvies and in its crafty syntax, 'The Loaf' also connects directly with the twenty-four line two-sentence double-sonnet 'The Stoic' (37). This poem exudes philosophical quietude in the face of the vicissitudes of life, an individual composure that also entails civic duty. This centrepiece relates to the indefinite wound of the opening poem, and incorporates many of the tropes and traumatic themes of the volume. 'A burlapped fawn half-way across the iced-over canal,' an image of precariousness and imminent danger, is conflated with the sacrificial labour of an Irish navvy who dug the

31 Prov. 20: 17; St. Matthew 7: 9. Ciaran Carson's 'Loaf' offers another contemplation on the labours and products of physical work and imaginative contemplation in Belfast Confetti, 15-18.

32 For some of Yeats's striking refrains, see 'The Madness of King Goll,' 'The Stolen Child,' 'The Meditation of the Old Fisherman, 'The Ragged Wood,' 'The Happy Townland,' 'September, 1913, 'Beggar to Beggar Cried, ' 'Running to Paradise,' 'The Mountain Tomb, 'Easter 1916,' the Crazy Jane cycle, 'Three Songs to the Same Tune,' 'What Then?' 'The Curse of Cromwell,' 'The Ghost of Roger Casement, 'The O'Rahilly,' 'The Wild Old Wicked Man,' 'The Pilgrim,' 'Colonel Martin,' 'Three Marching Songs,' 'Long-Legged Fly,' 'The Apparitions,' 'The Statesman's Holiday,' 'The Black Tower.' Muldoon praises MacNeice's poem 'The Taxis,' which sports an ingenious refrain, for 'the tone of voice and the humour and the bleakness of it, and the fluency and the surreal element of it, and yet the fact that in the middle of all this great invention it never leaves the real world. I'd love to be able to write a poem like that.' Perhaps this is the one? Paul Muldoon, interview by Clair Wills, Nick Jenkins and John Lanchester, 1987. 
canal through the rhymes of 'fawn' and 'griffawn' (37). This sense of existential fragility and human suffering is personalised by individual tragedy, Muldoon's own in fact, when the speaking subject receives the news of losing their child in a phone call from his wife. This moment of introspection and human poignancy under the Gateway Arch in St. Louis apprehends the utmost solitary desolation. The sequestered position under the arch aligns the bereaved with the stoics, as the word stoic stems from 'meeting under doorways,' and with the strife and endurance of the Irish navvy through the bleeding instep of his foot. Arches extend to tombstone masonry and graveyard portals, and parallel the memorial bows of yew and Osage orange. Arches also give shape and significance to the poem as they span transhistorical sorrows and illustrate the poem's architecture. The final verses of this two-sentence double sonnet present two fawns and two Irish navvies as a vision riven by heartfelt pain or suffused by tears, a poetic twinning to assuage in art the loss of the child. Conversely, the gateway also marks a place of transition in time and place, a moment of looking back on sorrows, facing up to them, and moving on:

when I got your call in St Louis and, rather than rave as one might rant and rave at the thought of the yew from Deidre's not quite connecting with the yew from Naoise's grave,

rather than shudder like a bow of yew or the matchless Osage orange at the thought of our child already lost from view

before it had quite come into range, I steadied myself under the Gateway Arch

and squinted back, first of all, through an eyelet of bone to a point where the Souris

had not as yet hooked up with the Assiniboine, to where the Missouri

had not as yet been swollen by the Osage, then ahead to where - let's face it - there are now two fawns on the iced-over canal, two Irish navvies who've stood there for a veritable age With their long-tailed shovels or broad griffawns. $(37-38)$

Despite the poem's dominant sense of unity and harmony, there are several intimations of adversity. Fluctuations of life are reflected in the Heraclitean flux of rivers Souris, Assiniboine, Missouri and Osage, and in the unstoppable 
pluralities of language. 'Assiniboine' implies Arabian murderers and the Battle of the Boyne, just as 'Osage Orange' hints at Amerindian persecution and religious wars. Deirdre and Naoise evoke mythical lives of love and murder, but and failure of the yews from their graves to connect retains a denial of metaphysical reunion. 'The Stoic' places private calamity at the center of mythic tragedy and historical massacres, but these artistic attempts to transcend and reconceptualise human misery are entangled in a language that is already violently plural. Muldoon confronts this comprehensive bleakness with a remarkable lack of sentimentality, and this lack of self-commiseration discloses a stoic stance that to some degree provides a moral alibi for Muldoon's adamant revisionist attitude in the volume.

These previous poems and conversations converge in the final remarkable poem, 'At the Sign of the Black Horse, September 1999.' The title points to equestrian and Amerindian tropes, but also highlights the significance of semiosis and syntax. The phrase signals the deliberate use of syntactic segments, line and sentence in this concluding poem. Specifying a time and place, New Jersey in the wake of Hurricane Floyd, the title also reveals a semiotic awareness that ponders its own representational capacities. In its prepositional positioning of a natural place name, the title alludes to Flann O'Brien's At Swim-Two-Birds, another multilayered text of subtle ironies and revisions. One of the poem's multidiscursive sign systems is its dialogue with Yeats. Muldoon's prayer for his own son, Asher, evokes Yeats's 'A Prayer for My Daughter,' but also relates to 'In Memory of Major Robert Gregory' and the first section of 'In Time of Civil War' titled Ancestral Houses in its revival of past family members, and in its meditations in times of dramatic change. This final text also accumulates concerns and themes that run throughout the volume, for example the green wound and the hard drives from the first poem, the relations between the Irish-American and Jewish-American couple in 'The Grand Conversation,' and the compassion for family and past lives in so many of the poems. Mixed marriage, canal construction, the Holocaust and the complexities of contemporary life are conveyed with a technical gusto that moves the reader, and that intertwines with astonishing alacrity the many words, rhythms, themes and tropes of the preceding poems that lead up to this climax. Legacies of death and annihilation flow in these forty-five stanzas that focus mainly on how new generations have to negotiate their own family, traditions and history - the prospects of a future as they present themselves to the innocent child in the pram, Muldoon's son, Asher. The achievement of 'radical innocence' in its many forms, a Yeatsian key repetition in the verse, is a premeditated act of resisting orders of all kinds that appear in the poem as peremptory pronouncements. With pointed religious irreverence, the verses refer to fraud, 
crime and murder in the Rothstein scandals and the Jewish mafia, they recount how Asher is denied religious rites, and they revel in a peccary barbecue. The verses radically challenge any purist orthodoxy, whether Jewish, poetic, aesthetic or linguistic. Alliterative connections and allusive connotations of 'peccary' (unclean meat) with 'peccavi' (acknowledgement of sin) and 'peccadillo' (trifling offence) indicate these intricacies. Phrase, clause and sentence, enjambment and free lines undulate with the flood and ebb of Hurricane Floyd:

bearing clay, hay, hair (at shoulder height, or above)

through the awesome

morning after Hurricane Floyd as yet another 1921 Benz or 1924 Bugatti came down Canal Road and yet another peaked cap was enquiring of my child-kin the meaning of 'Ashkenaz,'

Place Mask Over Mouth and Nose, my trepidation becoming more and more pronounced as that smoke would flail and fling itself over Auschwitz. I looked up from our make-believe version of Boscobel Beach to a cauterized stump of sassafras or sycamore

as the creel carters piled more and more clay, hay, hair,

spectacle frames, Willkommen, on to the line of carrioles and camions by the edge of the flooded stream, those creel carters imagining in excited reverie the arches of the bridge wrought with the motto Arbeit Macht Frei, while I looked up through the swing and swale of smoke, Please Leave A Message After The Beep, (82-83)

Benz and Bugatti appear as mobile antiquities with a hard drive from previous poems, and from the time and profits of illegal liquor trafficking by Jewish predecessors to the Irish canal diggers at the moment when an outsider, as the mispronunciation of 'Ashkenaz' reveals, literally questions the Jewish tradition. Ashkenazi inserts in a single response the majority of Jews in the ashes of the Nazi concentration camps and excludes by silence the Sephardi minority. At the same time, the term also introduces the art of the Jewish pianist from Russia, Vladimir Davidovic Ashkenazy, who emigrated to London and Iceland. Many of the interpolated orders in the poem, in the form of imperative sentences, refer directly to the horrors of Auschwitz, and indirectly to numerous situations of flight, crime, massacre and recording of verbal messages. 
Conflations of names and traditions, codes and messages, past and present, convey the end of any single discourse or dominant version of the past and the present: these are the multiple metanarratives into which Asher and the new generation are born. In its radical form, linguistic opprobrium and semiotic self-awareness, 'At the Sign of the Black Horse, September 1999' signals a revisionist attitude and scepticism about grand narratives, as the forty-five stanzas both subsume and rewrite the themes, tropes and techniques of the volume's forty-five poems, and thus initiates at the end a rereading of the book and, perhaps, Muldoon's oeuvre and textual templates. A total number of 360 lines buttresses such circularity; the stanzaic numerology recalls, for example, the composition of 'Incantata.' In like manner, the numerological importance of 45 stanzas also remarks the wWII cease-fire in 1945, and provokes a reinterpretation of cognitive formations of that trauma and, possibly, the preceding years of the catastrophe. These revaluations are not a cancellation of historical facts, but a questioning of what facts and traditions are selected and interpreted in what ways by which interests. In their traversal of disputed formal and linguistic terrain, these sentences also evince how the media, by which information and discourses of the known and the unknown circulate, are also subjected to aporia and alteration. In the aftermath of the linguistic century, presentations of the past and the present that ignore their own positions, delimitations and possibilities, risk foreclosure from the outset. The final sentence on the past is illusory.

Moy Sand and Gravel continues Muldoon's consistent exploration of language. The volume's metalinguistic dimension of questioning, measuring and analysing language drives the volume's critical and meditative approach to the phenomena of the past, and to the dilemmas of mortality. The volume combines his full armoury of lexical invention, turning of line and metamorphoses of form with a noticeable concentration on the sentence in all its meanings. Lines of variable texture and length, by which Muldoon conducts his bold linguistic ploys and allusive jugglery, elicit different responses from the settings in which they appear, and the horizons beneath which they are read. The linking of poems by vocabulary, allusion, contrast, rhythm, sound distribution, farfetched fantasy and various other uncanny strategies, in addition to their content, extends the boundaries of individual poems, pushing back their hermeneutic boundaries. The sentence, understood as syntax, pronouncement, logic and judicial decision, adds a new note of synthesis and construction to his poetry. Muldoon's frequent preference for alphabetic atomism and inconclusive lineality has stretched itself to embrace larger linguistic units. At a time of religious dogmatic inflexibility, of the stern fronts of decommissioning and of artistic demarcation, Muldoon, often in reciprocation with Heaney's poetics 
and Yeats's stanzaic stringency and passionate syntax, has hit upon a subtle and strict stylistic device in his dedication to serve his sentence. It is a fitting and ironic, but very unfortunate, imposition that the book's format cuts short the long sentences and disfigures many of the poems' artistic designs. This imposition of print and page restrictions, not unlike the italicisation in the first edition of New Weather, indicate a different dimension of power with which the written word often relates. Still full of sombre Adorninan concerns, in its typical Muldoonian idiosyncrasy and its many turns of sentence, Moy Sand and Gravel offers a more sentential side to the language of Muldoon's poetry, and issues an existentialist reminder that life is indeed no more than "a misprint / in the sentence of death."' 